tion. Now it is ingrained in the public consciousness as the epitome of a fossil, an exquisite testament both to evolution and to a plucky little bird launching itself unsteadily into a hostile world, endowed with a preternatural sense of responsibility for its innumerable descendants. Archaeopteryx has become a kind of Jurassic Otto Lilienthal.

Only a direct challenge of its status as primordial bird could unseat it from its perch, but nothing less is promised by an article to appear this Saturday (29 June). It describes a bird far more birdlike than Archaeopteryx that was alive and flying 75 million years earlier. Fittingly, the article appears in Philosophical Transactions (332B, 277-342), and will cause similar consternation. The evidence for the new early bird consists of two partial skeletons from the 225-millionyear-old Dockum formation of Texas which, if they are validated, would make Archaeopteryx merely a throwback in a world otherwise presumably teeming with advanced birds, as much a relic of a vanished age as is the platypus today among mammals.

So palaeontologists will be as sceptical of what Sankar Chatterjee of Texas Tech calls Protoavis texensis as was Owen of his own creation. Even by the leisurely standards of the field, Protoavis has been a long time hatching. The fossils were found as long ago as 1983, and their progress into the literature has been marked by a lone and tantalizing abstract, itself now four years old. Even the monographic treatment now given it will fail to satisfy: it discusses only the cranial anatomy in any detail. A discussion of the postcranial anatomy - and the all-important flight capability of Protoavis

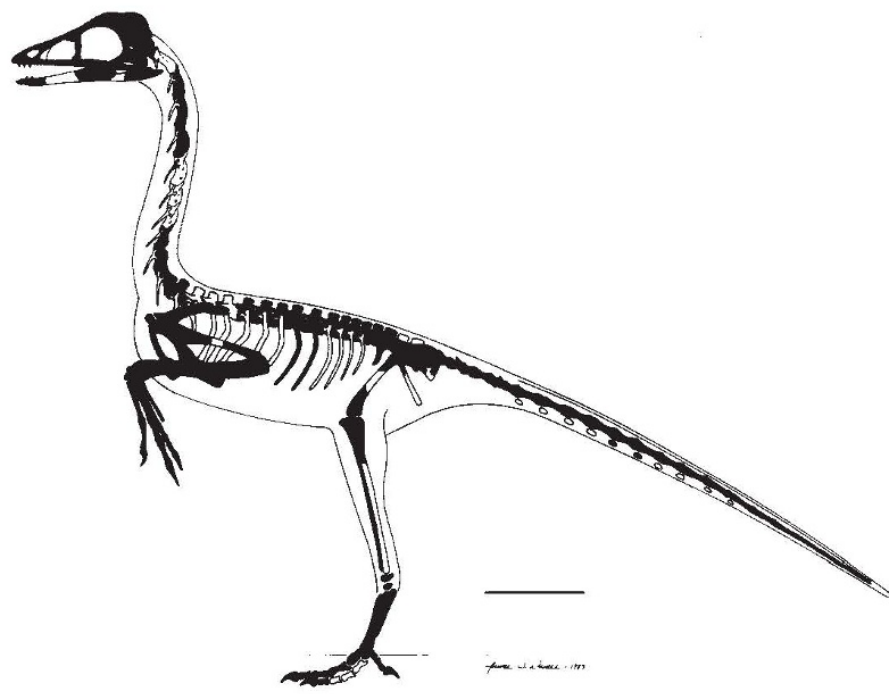

Protoavis texenis, n. sp. - composite skeletal restoration representing the size and proportion of a large individual. Scale bar, $5 \mathrm{~cm}$. (Reproduced with the permission of The Royal Society.)

which, incidentally, does not arrive clothed in feathers - is promised for later. The presence of a few more bird bones from another site in Texas are hinted at even more elliptically. Yet again, these are promised for a separate paper. Palaeontologists who have known about Protoavis for years, but have had to make do with rumour and guesswork - and even restorations in popular books - will want to know much more before they will believe it is the real thing. Perhaps Owen, after all, will have had the last laugh.

\section{Back to old Berlin}

The choice of Berlin as the new capital of Germany is good for Germany and for the rest of us.

LAST week's decision by the German Bundestag that the German capital should be moved from Bonn to Berlin may have surprised the pundits and dismayed most of those who work in Bonn, but it is both sensible and imaginative. The most immediate benefit will be that accruing to the eastern states of Germany, for which it is economically, culturally and politically important that something more should be made of the city of Berlin than a lasting monument to the period during which Germany was divided.

And the geographers' complaint that Berlin is "too far East" merely means that it is inconveniently placed for those who already have well-beaten paths of travel from which they will deviate only with difficulty. It is, in any case, as fair to argue that a capital not far from the border with Poland and with Czechoslovakia will help not just Germany, but the rest of Europe, look eastwards, where there is a great deal of interest.

The canard that making Berlin the capital of Germany will serve only to restore German militarism and a sense of power is a more interesting but even less worthy objection. The desultory, but absorbing, items published in our Correspondence columns in the past few months about the causes of the Third Reich and its abberrations have uncovered little new, but may have reminded many readers that Germany's traditions are as liberal as most would reasonably ask. And even in the twentieth century, Berlin is more readily recalled for Berholt Brecht as for Adolf Hitler, who went north with something of the diffidence that Bonn's civil servants will now move east. But that will take a long time. Could science ease the path by using the designation of Berlin as a way of creating the membership disciplinary societies most conspicuous in Germany by their absence?

\section{Jobs wanted?}

Nature is this week launching a new service for readers from this issue, we shall include a 'Positions Wanted' section in the Classified Advertisements section.

It is not merely that economic ups and downs (mostly in the West) and political upheavals (in Eastern Europe, the Soviet Union and the Middle East) have left some professional people without jobs, but that recent research among Nature's 500,000 readers suggests that 60 per cent of them would be willing to move to positions in other countries.

The Positions Wanted column is meant to meet international needs, but should also cater for those who would prefer to stay at home. To launch the service, we shall publish two advertisements for the price of one. Full details may be found on Classified page 18. 